\title{
Bacterial and Viral Pathogens, Molecular Mechanisms and Cellular Toxicity
}

\author{
Iqra Kanwal ${ }^{1}$, Sana Riaz ${ }^{2}$, Faisal Nadeem ${ }^{3}$, Saba Manzoor ${ }^{4}$, Abdul Jabbar ${ }^{2 *}$, Aneeza Shafqat ${ }^{2}$, Mudssar Aslam ${ }^{4}$ \\ ${ }^{1}$ Department of Biochemistry, University of Agriculture, Faisalabad, Pakistan \\ ${ }^{2}$ Institute of Microbiology, University of Agriculture, Faisalabad, Pakistan \\ ${ }^{3}$ Centre of Agricultural Biochemistry and Biotechnology, University of Agriculture, Faisalabad, Pakistan \\ ${ }^{4}$ Department of Zoology, Wildlife and Fisheries, University of Agriculture, Faisalabad, Pakistan
}

DOI: $10.36348 /$ sijap.2021.v04i04.001

| Received: 18.03.2021 | Accepted: 25.04.2021 | Published: 30.04.2021

*Corresponding author: Abdul Jabbar

\section{Abstract}

Viruses as pathogens have ability to replicate in the particular host in order to damage their organs. Some bacterial pathogens cause lethal diseases associated with metabolisms. Bacteria also increase the rate of infection due to antibiotic resistance. There is need to design such drugs that control the specific targets of bacterial strains. Streptococcus type also causes the diseases associated with medical conditions such as pneumonia. Shigella as well as Salmonella also causing the diseases in food and food products. Pseudomonas syringae as one of the bacterial pathogens that attacks on the leaves as well as different parts of plants that finally damaged to whole plant. $S$. pneumoniae is the pathogenic bacterial strain that causes severe inflammation in the lungs by damaging to the lungs. E. coli as the type of bacterial pathogen that enter into the intestine of the human. It particularly stays here and multiplies to increase its infection to damage the specific parts of intestine. Chikungunya virus is spread to people by the bite of an infected mosquito. The most common symptoms of infection are fever and joint pain. The DENV genome is about 11000 bases of positive-sense, single stranded RNA (ssRNA) that codes for three structural proteins. At present, CYD-TDV or Dengvaxia ${ }^{\circledR}$ is the only approved vaccine, but potent inhibitors are currently under development.

Keywords: Viral Infections, Bacterial infections, dengue, microbes, genetic engineering.

Copyright (C) 2021 The Author(s): This is an open-access article distributed under the terms of the Creative Commons Attribution 4.0 International License (CC BY-NC 4.0) which permits unrestricted use, distribution, and reproduction in any medium for non-commercial use provided the original author and source are credited.

\section{INTRDOCUTION}

Rinderpest viruses reported firstly of a rapidly growing list of causative agents of major infectious diseases of domestic animals that at the beginning of the twentieth century led to the establishment of the discipline of animal virology [1,2]. A few examples of other animal viruses discovered in those early days are those associated with African horse sickness (AHS), rabbit myxomatosis, fowl plague (avian influenza), and avian leucosis [3-5].

As water contains variety of pathogens and other microbes that directly enter into the human body. Through drinking water and polluted water, many murices damage the cells of living organism. Water gets polluted day by day due to serious water pollution in environment. Polluted water has large number of toxic heavy metals that rennet kills the living cells. While on the other hand, vegetable also source of microbes that damage the plant as well as large population of human [6]. Vegetable and fruits that directly harvested through farms exhibit large number of bacteria. It is better to clean the vegetables and fruits though healthy environment as compared to the chemical sprays that damage the animals as well as plants. Huge number of plants and animal have been affected through chemical sprays [7-10]. 


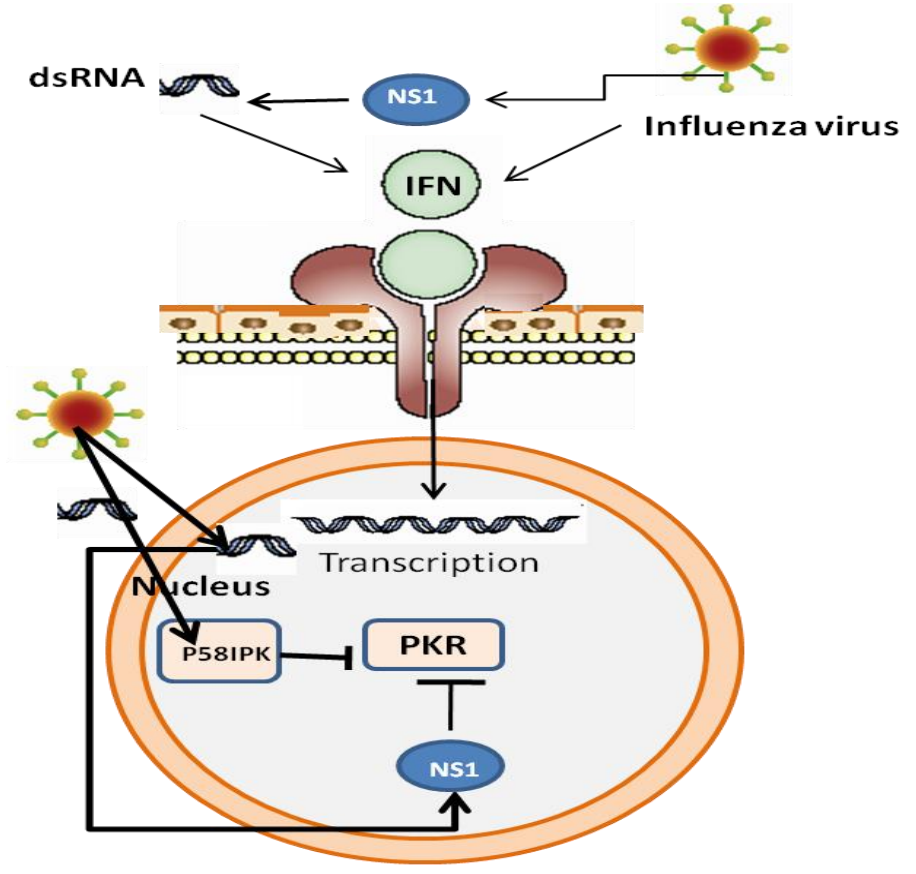

Fig-1: Shows the viral mechanism of interplay of genes at cellular level

Viruses are the group of particles that have ability to replicate in the particular host in order to damage their organs [11]. Some viruses containing the genetic material in the form of DNA while on the other hand, some other containing the genetically material in the form of RNA. There are different types of viruses in which some of them are more lethal and causes the more serious disease in human as well as in plants. One of the viruses the infected the people all around the world is the COVID-19 that is transmitted through infected person already suffering form that disease. It has different strains depends upon the particular strain. This virus rapidly infect the air passage of human and transmitted from person to person due to its rapid replication in the living cells [12-14].

Bacteria also increases the rate of infection due to antibiotic resistance. There is need to design such drugs that control the specific targets of bacterial strains. Molecular biology and genetic engineering employed the approach to target and design specific drugs that kills the large variety of bacterial strains. Each bacterial strain rapidly multiplies due to growth factors that activating their replication father than normal. Bacteria need specific temperature to grow and survive under different environmental conditions [15].

\section{Role of Bacterial Pathogens}

Some bacterial pathogens caused lethal diseases associated with metabolisms, One of the important diseases is the tuberculosis that affected the cells of lungs by increasing infection rate at high level. This diseases is due to the mycobacterium tuberculosis that affected the population all around the world. Streptococcus type also causes the diseases associated with medical conditions such as pneumonia. Shigella as well as Salmonella also causing the diseases in food and food products. These bacteria also affected the large quantity of foods all around the world due to increase resistance [16-19].

Pseudomonas syringae as one of the bacterial pathogens that attacks on the leaves as well as different parts of plants that finally damaged to whole plant. It depends upon on the severity of attacked and type of particular strain of $\mathrm{P}$. syringae. The more pathogenic strain of the P. syringae, the more attacked to the plant leaves that cause more wilting. The less pathogenic strain of the P. syringae, the less attacked to the plant leaves that causes less wilting. The genome of $\mathrm{P}$. syringae has been studied to get information about their interaction to plant [20]. 
Iqra Kanwal et al; Sch Int J Anat Physiol, Apr., 2021; 4(4): 44-49

Coagulation

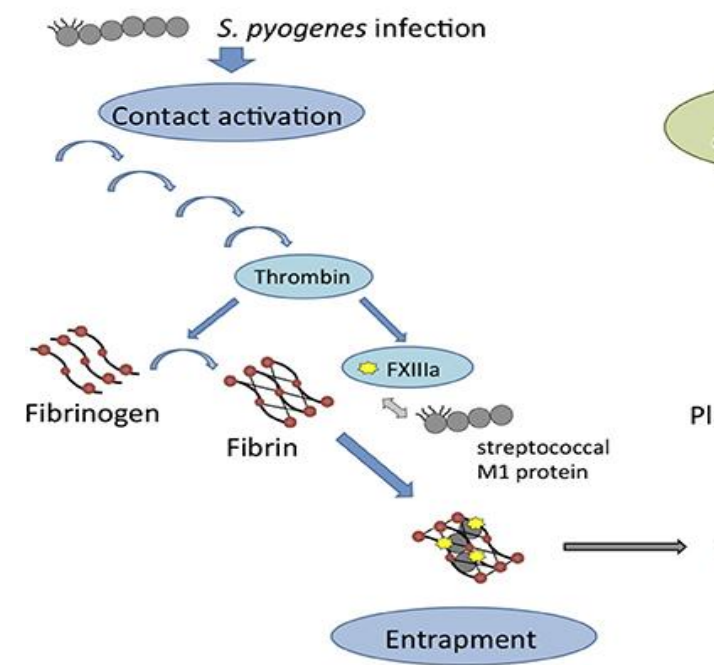

Fibrinolysis

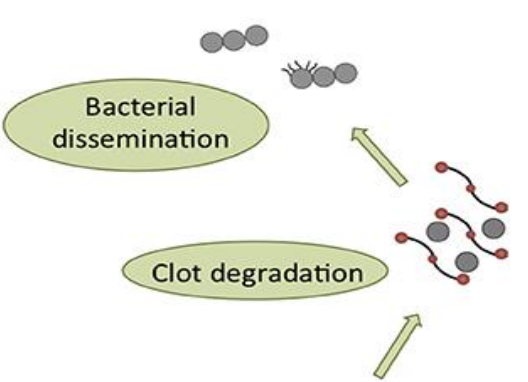

Plasminogen Plasmin

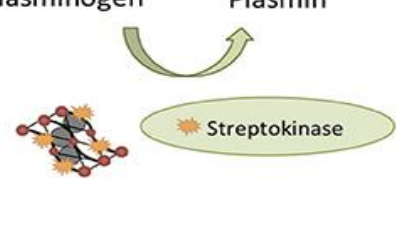

Fig-2: Shows the general mechanism of action of bacterial infection (S.pyrogens)

\section{Role of Streptococcus}

Streptococcus as most popular bacterial pathogen that have ability to grow rapidly as compared to other bacterial strain by forming the pairs of chains. They are aerobic as well as anaerobic depend upon the particular conditions. They are divided into different groups on the basis of causing the particular infections. Streptococcus pyogenes is a bacterial pathogen that affected the large populations of human including the children as well as adults. This bacterial pathogen causes the infection such as pharyngitis that takes serious form into chronic conditions if not treated properly [21-23].

Damaging to the lungs It blockage the cells of air passage ways and inhibit the air flow that resulted to severe inflammation. It is important to noted that this infection should be treated at early stage and it takes to chronic inflammation, it becomes difficult to relate for specific antibodies. There are two types of hemolysis tested for checking the bacterial infection. Alpha hemolysis resulted due to incomplete breakdown of membrane of blood cells. Beta hemolysis also occurs in infants due to more chances of infection at early age. It also skin infections as well as lungs [23-26].

\section{Role of Escherichia coli}

E. coli as the type of bacterial pathogen that enter into the intestine of the human. It particularly stays here and multiplies to increase its infection to damage the specific parts of intestine. It resulted the swollen and nonfunctional intestinal tract that leads to poor role in digestion. It leads to accumulation of fluids as well as food parts. This type of bacteria also gavage the give tract of animals by inhibiting the flow of food material from digestive tract to the various parts of digestive system. Some antibiotics are available to control their growth but due to bacterial resulted action of antibiotics have been reduced [27].
E.coli also transmitted into the human body through polluted foods. The animal's husbandry exhibits a variety of cattle that eat different types of grasses. These are directly entered into the body of cattle and other animals. When meat from these animals proceeded by human, most of bacteria enters into the cells of body and kills them. Milk also forms dairy and milk based products exhibits loss of bacteria. It is diffusely to kills the pathogens and microbes directly from cattle. The first and easy way to protect living cells is the boiling of milk or provides heat at spiffiest temperature in order to kills the growth of bacterial cells. Usually, at high temperature, most of the bacteria die due and not survive for longer periods of time [2832].

Symptoms appear after the attacking of E. coli into the particular host depending upon on the immune system. The person with weak immune system has more chances of attack of this attack as compared to their viruses while on the other hand, symptoms such as muscle cramp due to deficiency of calcium supply leads to tetany. It also causes the diarrhea with extensive mitting and high temperature. These symptoms appear after the attack of bacteria and specking of patenting into the body. Then, it can be treated through antibiotics that either kills as well as dingbat the growth of microorganism at the carinas level. But, some medicines are needed to take more than normal due to bacterial resistance [33-37].

\section{Biological Role of Chikungunya virus}

Chikungunya virus is spread to people by the bite of an infected mosquito. The most common symptoms of infection are fever and joint pain. Other symptoms may include headache, muscle pain, joint swelling, or rash. Outbreaks have occurred in countries in Africa, Asia, Europe, and the Indian and Pacific Oceans. In late 2013, chikungunya virus was 
Iqra Kanwal et al; Sch Int J Anat Physiol, Apr., 2021; 4(4): 44-49

found for the first time in the Americas on islands in the Caribbean. There is a risk that the virus will be imported to new areas by infected travelers. There is no vaccine to prevent or medicine to treat chikungunya virus infection. Travelers can protect themselves by preventing mosquito bites. When traveling to countries with chikungunya virus, use insect repellent, wear long sleeves and pants, and stay in places with air conditioning or that use window and door screens [38].

The symptoms of chikungunya are similar to those of dengue and Zika, diseases spread by the same mosquitoes that transmit chikungunya [39].

\section{Dengue Virus and its influence on human population}

Until a few hundred years ago, dengue virus was transmitted in sylvatic cycles in Africa, Southeast Asia and South Asia between mosquitoes of the genus Aedes and nonhuman primates, with rare emergences into human populations. The global spread of dengue virus, however, has followed its emergence from sylvatic cycles and the primary lifecycle now exclusively involves transmission between humans and Aedes mosquitoes. Vertical transmission from mosquito to mosquito has also been observed in some vector species. Dogs have been found to be infected by the virus, but more research is needed to determine if dogs or other animals can serve as reservoirs or are just incidental hosts [40].

The DENV genome is about 11000 bases of positive-sense, single stranded RNA (ssRNA) that codes for three structural proteins (capsid protein $\mathrm{C}$, membrane protein $\mathrm{M}$, envelope protein $\mathrm{E}$ ) and seven nonstructural proteins (NS1, NS2a, NS2b, NS3, NS4a, NS4b, NS5) [4]. It also includes short noncoding regions on both the 5 ' and 3 ' ends [41].

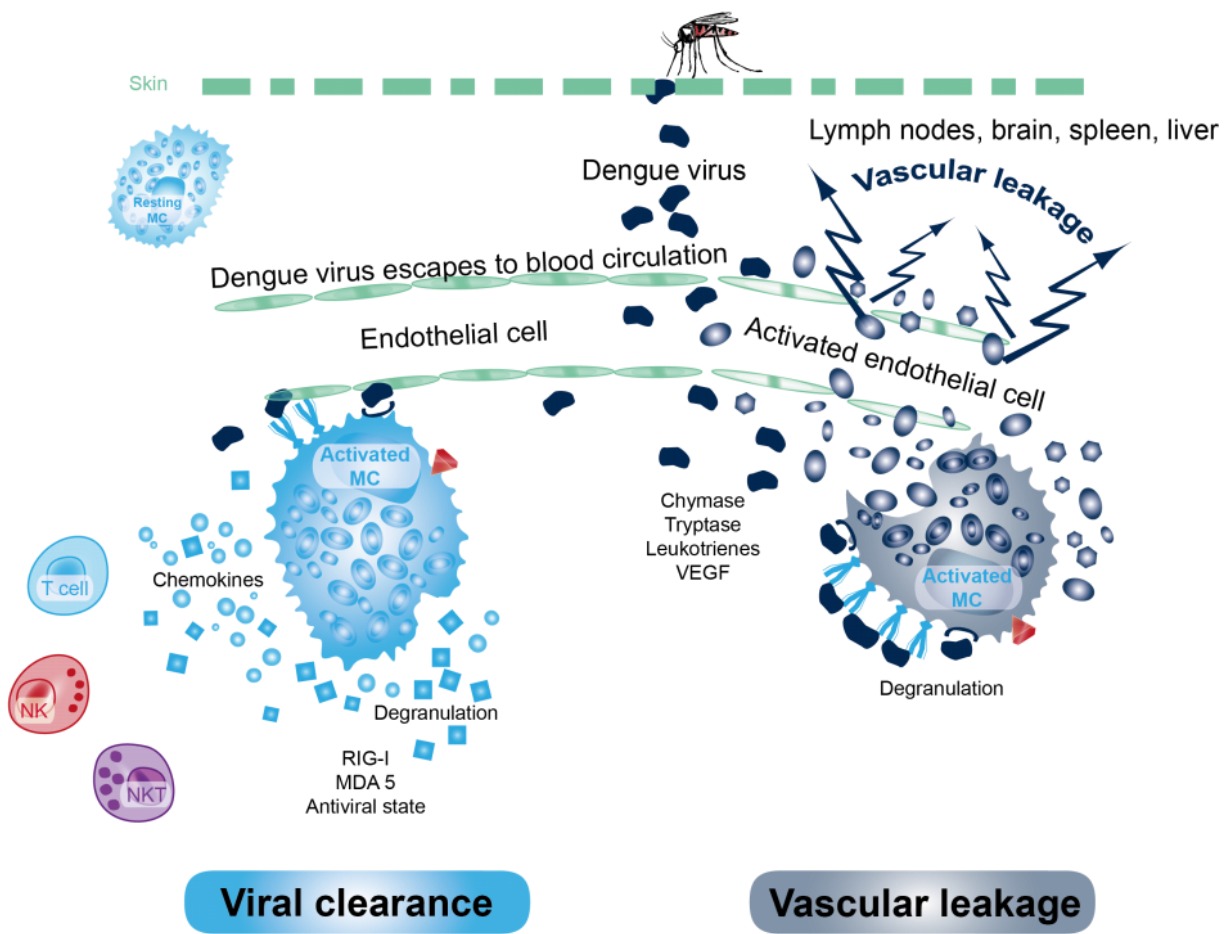

Fig-3: Shows the attacking mechanism and replication of dengue virus

The global occurrence of viral infectious diseases poses a significant threat to human health. Dengue virus (DENV) infection is one of the most noteworthy of these infections. Numerous foundational and clinical investigations on viral epidemiology, structure and function analysis, infection source and route, therapeutic targets, vaccines, and therapeutic drugs have been conducted by both academic and industrial researchers. At present, CYD-TDV or Dengvaxia $^{\circledR}$ is the only approved vaccine, but potent inhibitors are currently under development. These successes and failures have enabled progress in anti-
DENV drug discovery and hope that our review will stimulate further innovation in this area [42].

\section{CONCLUSION}

Different diseases caused by viruses and bacteria from animals and plants have different sources of infections. Infectious diseases rate increasing day by day due to resistance of pathogens. Antibiotics effective for treating the microbes but there is need for genetic engineering top control the diseases rate at cellular and molecular level. Cellular study at gene level helpful to 
Iqra Kanwal et al; Sch Int J Anat Physiol, Apr., 2021; 4(4): 44-49

control the pathogenicity of different microbes responsible for infections in specific host.

\section{REFERENCES}

1. World Health Organization. (2019). Progress report on HIV, viral hepatitis and sexually transmitted infections 2019: accountability for the global health sector strategies, 2016-2021 (No. WHO/CDS/HIV/19.7). World Health Organization.

2. Huang, Q. S., Wood, T., Jelley, L., Jennings, T., Jefferies, S., Daniells, K., ... \& Webby, R. J. (2021). Impact of the COVID-19 nonpharmaceutical interventions on influenza and other respiratory viral infections in New Zealand. Nature communications, 12(1), 1-7.

3. Borrmann, H., McKeating, J. A., \& Zhuang, X. (2021). The circadian clock and viral infections. Journal of biological rhythms, 36(1), 922.

4. Cummings, L., Tucker, M., Gibson, M., Myers, A., Pastinen, T., Johnston, J., ... \& Sampath, V. (2021). Rare genetic variants in immune genes and neonatal herpes simplex viral infections. Pediatrics, 147(1).

5. Shahid, A., Ali, S., Zahra, T., Raza, M., Shahid, A., Saeed, M. U., \& Javaid, F. Influence of Microbes in Progression of Cancer and DNA Damaging Effects.

6. Iftikhar, A., Shahid, A., Shah, S. S., Ali, S., Raza, M., Ali, E., \& Umbreen, S. Antimicrobial Activities of Selected Medicinal Plant with Potential Role of Chemical Compounds.

7. Naeem, M., Hayat, M., Qamar, S. A., Mehmood, T., Munir, A., Ahmad, G., ... \& Hussain, A. (2019). Risk factors, genetic mutations and prevention of breast cancer. Int. J. Biosci, 14(4), 492-496.

8. Shafiq, S., Adeel, M., Raza, H., Iqbal, R., Ahmad, Z., Naeem, M., ... \& Azmi, U. R. (2019). Effects of Foliar Application of Selenium in Maize (Zea Mays L.) under Cadmium Toxicity. In Biological Forum-An International Journal (Vol. 11, No. 2, pp. 27-37).

9. Ahmad, I., Khan, S., Naeem, M., Hayat, M., Azmi, U. R., Ahmed, S., ... \& Irfan, M. (2019). Molecular Identification of Ten Palm Species using DNA Fingerprinting. Int. J. Pure App. Biosci, 7(1), 4651.

10. Usman, G., Muhammad, N., Hamza, R., Usman, I., Ayesha, A., Saqib, U., ... \& Fatima, Q. (2019). A Novel Approach towards Nutraceuticals and Biomedical Applications. Scholars International Journal of Biochemistry, 2(10), 245-252.

11. Naeem, M., Ali, J., Hassan, M. Z., Arshad, B., Rao, M. H. I., Sarmad, M. S. K., ... \&amp; Hassan, M. U. (2019). Novel Approach towards DNA Barcoding as a Tool in Molecular Biologyand Biological Activities of Cyclotides with Particular Emphasizes at Molecular Level. In Biological Forum-An International Journal, 11(2), 83-96.
12. Škare, M., Soriano, D. R., \& Porada-Rochoń, M. (2021). Impact of COVID-19 on the travel and tourism industry. Technological Forecasting and Social Change, 163, 120469.

13. Naeem, A., Saddique, S., \& Chand, S. A. (2019). Advancement and Future Directions towards Herbal Treatment for Various Diseases.

14. Kim, J. H., Marks, F., \& Clemens, J. D. (2021). Looking beyond COVID-19 vaccine phase 3 trials. Nature medicine, 27(2), 205-211.

15. Naeem, M., Ashraf, A., Safdar, H. M. Z., Khan, M. Q., Rehman, S. U., Iqbal, R., \& Ahmad, G. (2020). Biochemical changes in patients with chronic kidney failure in relation to complete blood count and anemia. IJB, 16(1), 267-271

16. Sachs, J. D., Karim, S. A., Aknin, L., Allen, J., Brosbøl, K., Barron, G. C., ... \& Bartels, J. (2021). Priorities for the COVID-19 pandemic at the start of 2021: statement of the Lancet COVID-19 Commission. The Lancet.

17. Naeem, M., Hussain, A., Azmi, U. R., Maqsood, S., Imtiaz, U., Ali, H., ... \& Ghani, U. (2019). Comparative Anatomical Studies of Epidermis with Different Stomatal Patterns in Some Selected Plants Using Compound Light Microscopy. International Journal of Scientific and Research Publications, 9(10), 375-380.

18. Ahsan, M., Aslam, M., Akhtar, M. A., Azmi, U. R., Naeem, M., Murtaza, G., ... \& Shafiq, S. (2019). Effect of inoculation of three rhizobial strains on maize hybrids. Journal of Biodiversity and Environmental Sciences, 14(6), 168-177.

19. Hazafa, A., Batool, A., Ahmad, S., Amjad, M., Chaudhry, S. N., Asad, J., ... \& Ghani, U. (2020). Humanin: A mitochondrial-derived peptide in the treatment of apoptosis-related diseases. Life Sciences, 264, 2021, 118679.

20. Rafeeq, H., Ahmad, S., Tareen, M. B. K., Shahzad, K. A., Bashir, A., Jabeen, R., ... \& Shehzadi, I. Biochemistry of Fat Soluble Vitamins, Sources, Biochemical Functions and Toxicity. Haya: The Saudi Journal of Life Sciences

21. Ghani, U., Naeem, M. Bukhari, S. S. H., Yar, G., Tariq, I., Siddique, S., Nawaz, H. A., Pal, Z. A. A., Nasim, F. and Bukhari, S. A. H. (2019). Prevalence and Risk Factors associated with Hepatitis B and Hepatitis C and their Correlation with Inflammatory Markers among Southern Region of Punjab. Biological Forum - An International Journal, 11(2): 136-143.

22. Muhammad Naeem, Umair Rasool Azmi, Sarmad Ahmad Qamar, Ahmad Munir, Tariq Mahmood, Muhammad Adeel Faryad. 2019. Reliable vaccine production by using Risk Based Bioengineering Strategies. 6th International Conference on "Sustainable Agriculture in Changing Climate: Strategies and Management. 261.

23. Rafeeq, H., Arshad, M. A., Amjad, S. F., Ullah, M. H., Muhammad, H., Imran, R. K., ... \& Ajmal, H. 
Iqra Kanwal et al; Sch Int J Anat Physiol, Apr., 2021; 4(4): 44-49

Effect of Nickel on Different Physiological Parameters of Raphanus Sativus.

24. Ghani U, Naeem M, Bukhari SS, Yar G, Tariq I, Siddique S, Nawaz HA, Pal ZA, Nasim F, Bukhari SA. Prevalence and Risk Factors Associated with Hepatitis B and Hepatitis C and their Correlation with Inflammatory Markers among Southern Region of Punjab. (2019). Prevalence and Risk Factors associated with Hepatitis B and Hepatitis C and their Correlation with Inflammatory Markers among Southern Region of Punjab. Biological Forum - An International Journal, 11(2): 136-143

25. Usman Ghani, Muhammad Naeem.2019. Safety assessment of immune mediated reaction to Novel Food Proteins. 6th International Conference on "Sustainable Agriculture in Changing Climate: Strategies and Management. 282

26. Muhammad Naeem Ahmad Munir, Shabaz Shafiq. 2019. The Role of Microbes in coffee Fermentation and Their impact on Coffee Quality. 1st international Conference on Sustainable Agriculture: Food Security under Changing Climate Scenarios. 56

27. Garrett, K. A., Nita, M., De Wolf, E. D., Esker, P. D., Gomez-Montano, L., \& Sparks, A. H. (2021). Plant pathogens as indicators of climate change. In Climate change (pp. 499-513). Elsevier.

28. Muhammad Naeem Jabir Ali, Ahmad Munir. (2019). Phenolic compounds as a Benchmark for Food Quality. 1st international Conference on Sustainable Agriculture: Food Security under Changing Climate Scenarios. 56.

29. Ahmed, M., Jabir, A., \& Muhammad, N. (2019). Improvement of Fruit and Vegetable quality through Postharvest Biology. 1st international Conference on Sustainable Agriculture: Food Security under Changing Climate Scenarios, 61.

30. Muhammad Adeel, Shahbaz Shafiq, Muhammad Naeem, Ihtisham Ali baber, Muhammad Ali, Rashid Iqbal. 2019. Interactive effect of ascorbic acid and melatonin on morphophyiological and ionic attributes of Okra challenged with salt stress. 1st international Conference on Sustainable Agriculture: Food Security under Changing Climate Scenarios.50

31. Iatta, R., Sazmand, A., Nguyen, V. L., Nemati, F., Ayaz, M. M., Bahiraei, Z., ... \& Otranto, D. (2021). Vector-borne pathogens in dogs of different regions of Iran and Pakistan. Parasitology Research, 1-10.

32. Syed Naeem Sajid, Arzoo Rubab, Nadia Azhar, Muhammad Naeem. (2019). Global Environmental Risks Factors and Non Communicable Diseases.
International Conference on Innovative Biological and Public Health Research, 78.

33. Muhammad, N., Ahmad, M., \& Sadam, H. S. (2019). Development and use of Molecular Markers in Health Care. International Conference on Innovative Biological and Public Health Research, 76.

34. Ahmad, M., \& Muhammad, N. (2019). Zika Virus Vaccine Development and New Challenges. International Conference on Innovative Biological and Public Health Research. 47

35. Jabir, A., \& Muhammad, N. (2019). Emergence of Mosquito Borne Viral diseases in Pakistan. International Conference on Innovative Biological and Public Health Research. 47.

36. Iqra, M. N., \& Ahmad, M. (2019). Novel Approach towards vaccine development though Nanoparticles. International Conference on Innovative Biological and Public Health Research. 94.

37. Muhammad, N., Umair, R. A., Muhammad, I., \& Usman, G. (2019). Reducing Risks to Food security from climate change. First International Conference on Sustainable Agriculture: Food Security under Changing Climate Scenarios. 79.

38. Hoenes, K., Bauer, R., Meurle, T., Spellerberg, B., \& Hessling, M. (2021). Inactivation Effect of Violet and Blue Light on ESKAPE Pathogens and Closely Related Non-pathogenic Bacterial SpeciesA Promising Tool Against Antibiotic-Sensitive and Antibiotic-Resistant Microorganisms. Frontiers in Microbiology, 11, 3429.

39. Umair, R. A., Hamza, A. Q., Waseem, A. M., Naeem, M., Irfan, M., \& Arslan, A. (2019). Potassium influence crop yield and quality production. First International Conference on Sustainable Agriculture: Food Security under Changing Climate Scenarios. 73.

40. Muhammad, N. (2019). Principles of Biochemistry \& Biological Sciences. Nishtar Publications. First Volume. 464

41. Mraz, A. L., Tumwebaze, I. K., McLoughlin, S. R., McCarthy, M. E., Verbyla, M. E., Hofstra, N., ... \& Murphy, H. M. (2021). Why pathogens matter for meeting the united nations' sustainable development goal 6 on safely managed water and sanitation. Water Research, 189, 116591.

42. Priest, S. J., Coelho, M. A., Mixão, V., Clancey, S. A., Xu, Y., Sun, S., Gabaldón, T., \& Heitman, J. (2021). Factors enforcing the species boundary between the human pathogens Cryptococcus neoformans and Cryptococcus deneoformans. PLoS genetics, 17(1), p.e1008871. 